
СІЛЬСЬКОГОСПОДАРСЬКИХ ПІДПРИЕМСТВ: ПОНЯТТЯ ТА Ії ОСНОВНІ ФУНКЦії

\author{
Halas L.I., \\ postgraduate student, junior researcher fellow at the \\ department of management and business administration, \\ Vasyl Stefanyk Precarpathian National University, \\ Ivano-Frankivsk
}

\title{
STRATEGY OF FOREIGN ECONOMIC ACTIVITY OF AGRICULTURAL ENTERPRISES: CONCEPT AND ITS MAIN FUNCTIONS
}

Постановка проблеми. Галузь сільського господарства України є однією 3 провідних в структурі національної економіки країни та показує позитивні тенденції розвитку, особливо враховуючи кризові явища в країні. Набуття Україною повноцінного членства в СОТ, глобалізація світової економіки, послаблення економічних бар'єрів та лібералізація економічних відносин між Україною та країнами ЄС сприяли інтеграції вітчизняних ринків сільськогосподарських товарів у світовий економічний простір. Не менш важливими $€$ сприятливі природні та кліматичні умови, наявність чорноземів на більшості території України, що дає можливість для розвитку сільського господарства України та нарощування його потенціалу.

Світовий ринок товарів та послуг є надзвичайно місткий, що, у свою чергу, передбачає широкі перспективи для підприємств, які функціонують на ньому, та водночас створює певні вимоги до менеджменту цих компаній. Розглядаючи сферу сільського господарства України, в якій однією 3 ключових ланок функціонування $\epsilon$ розвиток ефективної системи зовнішньоекономічних зв'язків, потрібно закцентувати увагу саме на розробку шляхів входу на світовий ринок. Включення цієї сфери у систему світової торгівлі та ефективна розробка стратегії зовнішньоекономічної діяльності підприємств сільського господарства сприятиме підвищенню техніко-економічного рівня виробництва продукції, більш ефективному використанню сировини і природніх ресурсів, та покращенню рівня життя та добробуту населення в цілому.

Українські сільськогосподарські підприємства при виході на зовнішні ринки в більшості випадків уникають стратегічного планування та управління своєю діяльністю. Відповідно, вони не можуть бути конкурентоспроможними у порівнянні з іноземними підприємствами, які активно застосовують методи стратегічного планування та управління.

Аналіз останніх досліджень і публікацій. Теоретичну та методологічну частину досліджень складають праці таких відомих вітчизняних та зарубіжних вчених економістів, як: М. О. Карпенко,

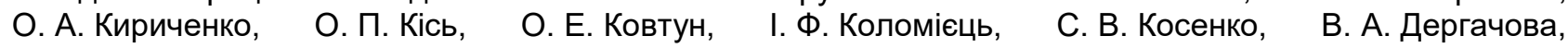
Г. В. Барабашіна, С. М. Качан, Г. Мінцберг, І. Ансофф, М. Портер та інші. Однак, в сучасних умовах господарювання та мінливому зовнішньому середовищі фрункціонування підприємств, стратегія зовнішньоекономічної діяльності швидко розвивається, набуваючи нових характеристик та форм, що і зумовлює постійне дослідження особливостей її розробки, впровадження та функціонування.

Постановка завдання. Метою статті $€$ дослідження основних тлумачень дефініції «стратегія зовнішньоекономічної діяльності» та виведення оптимального значення цього поняття для сільськогосподарських підприємств на основі функцій, які виконує стратегія для ефективного та конкурентоспроможного виходу на зовнішні ринки та подальшої діяльності цих підприємств на ринку.

* Науковий керівник: Якубів В.М. - д-р екон. наук, профресор 
Для досягнення мети було поставлено такі завдання: аналіз та вивчення сучасних підходів щодо визначення поняття «стратегія зовнішньоекономічної діяльності»; розгляд основних фуннкцій стратегії зовнішньоекономічної діяльності; розробка оптимального визначення поняття «стратегія зовнішньоекономічної діяльності сільськогосподарських підприємств».

Виклад основного матеріалу дослідження. Важливою складовою для ведення зовнішньоекономічної діяльності сільськогосподарськими підприємствами України є фоомування ефективної стратегії зовнішньоекономічної діяльності, адже від її правильної постановки залежить прибутковість самого підприємства, підвищення його конкурентоспроможності, якості продукції та безпосередньо його функціонування на зовнішніх ринках.

Слово «стратегія» походить від грецької мови та означає «військове ведення», «військове мистецтво» [1]. Дане поняття використовувалося для проведення військових операцій, які передбачали наперед сплановані та сформовані основні стратегічні завдання. А. Чендлер у 1962 році запозичив це поняття для ефективного ведення підприємницької діяльності. Стратегія підприємства це систематизований план дій, який спрямований на досягнення основної мети діяльності підприємства. На даний час вже існує багато визначень поняття « стратегія підприємства» [1].

Г. Мінцберг вважає, що «стратегія - це :

- плани керівництва щодо досягнення цілей та завдань підприємства;

- проходження певних моделей поведінки, лінії поведінки;

- позиція, розташування визначених товарів на конкурентних ринках;

- перспектива, основний спосіб дії підприємства;

- створення переваг перед конкурентами» [2, с. 11-12].

Відомий науковець І. Ансоффф стверджує, що «стратегія підприємства - це набір правил для прийняття рішень, якими керується підприємство у своїй діяльності, систематичний підхід, який забезпечує збалансований напрямок розвитку підприємства» [3, с. 46].

М. Портер розглядає стратегію як наступальні чи оборонні дії, спрямовані на створення стійкого становища в галузі, з метою успішного подолання п'яти чинників конкуренції i, отже, гарантування максимальної віддачі від капіталовкладень фрірми [4, с. 51].

Відомий науковець Б. Карлоф визначає стратегію як узагальнюючу модель дій, необхідних для досягнення поставлених цілей шляхом координації та розподілу ресурсів компанії [5].

У своїй праці П. Дойль висвітлює поняття «стратегія» як комплекс прийнятих менеджментом рішень з розміщення ресурсів підприємства та досягнення довгострокових конкурентних переваг на цільових ринках [6].

Розглядаючи поняття «стратегія зовнішньоекономічної діяльності», можна сказати, що це більш вузьке поняття, ніж поняття «стратегія», це один із видів загальної стратегії підприємства, вона є її невід'ємною складовою. Дана стратегія застосовується підприємством при виході на зовнішні ринки для продажу товарів чи надання послуг та включає в себе всі пріоритетні напрямки зовнішньоекономічної діяльності підприємства. Основними важелями при регулюванні діяльності даної стратегії є закони, законодавчі акти та нормативно-правова база країн, які здійснюють процес купівлі-продажу.

В табл. 1 подано основні визначення поняття «стратегія зовнішньоекономічної діяльності».

Таблиця 1

Визначення поняття «стратегія зовнішньоекономічної діяльності»

\begin{tabular}{|c|c|}
\hline Визначення & Джерело \\
\hline 1 & 2 \\
\hline $\begin{array}{l}\text { Стратегія ЗЕД - це напрям економічної стратегії, в якій розглядаються всі } \\
\text { альтернативні варіанти розвитку у сфері зовнішньоекономічної діяльності та їх } \\
\text { обґрунтування для прийняття рішення, правила та прийоми поведінки } \\
\text { підприємства на зовнішньому ринку в ролі як експортера, так й імпортера товарів } \\
\text { та послуг, визначаються принципи здійснення експортно-імпортних операцій } 3 \\
\text { урахуванням діючого законодавства }\end{array}$ & $\begin{array}{l}\text { Закон України від } 16 \\
\text { квітня } 1991 \text { року «Про } \\
\text { зовнішньоекономічну } \\
\text { діяльність» (п. } 8 \text { ст. 1) [7] }\end{array}$ \\
\hline $\begin{array}{l}\text { Стратегія ЗЕД - це план розвитку підприємства стосовно діяльності, пов'язаної з } \\
\text { виходом на зовнішній ринок, завоюванням бажаної частки ринку, розширенням та } \\
\text { підтриманням своїх позицій }\end{array}$ & О. П. Кісь [8, с. 29] \\
\hline $\begin{array}{l}\text { Стратегія ЗЕД - комплекс управлінських рішень, які звужують всю множину } \\
\text { можливих зовнішньоекономічних дій підприємства до сукупності найбільш } \\
\text { ефективних з точки зору довгострокових цілей, сформульованих у загальній } \\
\text { стратегії }\end{array}$ & С. В. Косенко $[9$, с. 29] \\
\hline $\begin{array}{l}\text { Стратегія ЗЕД - це функціональна стратегія, яка за ієрархією пов'язана } 3 \\
\text { конкурентною, ресурсною, товарною та іншими стратегіями підприємства }\end{array}$ & О.А.Кириченко [10, \\
\hline
\end{tabular}




\begin{tabular}{|c|c|}
\hline & продовження табл. 1 \\
\hline 1 & 2 \\
\hline $\begin{array}{l}\text { Зовнішньоекономічна стратегія полягає в досягненні економічних цілей на } \\
\text { світовому ринку, реалізується ж вона в процесі зовнішньоекономічної політики, } \\
\text { основою якої є державні законодавчі акти та доктрина національної безпеки }\end{array}$ & $\begin{array}{l}\text { В. А. Дергачова } \\
\text { с. 137] }\end{array}$ \\
\hline $\begin{array}{l}\text { Стратегія ЗЕД - це стратегія, яка випливає з об'єктивно існуючих порівняльних і } \\
\text { конкурентних переваг у різних галузях народного господарства і передбачає } \\
\text { пріоритет національних економічних інтересів в системі методів і фрорм } \\
\text { регулювання світогосподарських зв'язків, ґрунтується на засобах тарифного і } \\
\text { нетарифного регулювання, спрямована в цілому на створення конкурентного } \\
\text { ринкового середовища, поступове формування економіки, орієнтованої на експорт }\end{array}$ & $\begin{array}{l}\text { Г. В. Барабашіна, } \\
\text { С. М. Качан [12] }\end{array}$ \\
\hline
\end{tabular}

Джерело: розробка автора на основі [7-12]

Автором запропоновано таке визначення поняття «стратегія зовнішньоекономічної діяльності підприємства» - це ефективний інструмент виходу підприємства на зовнішні ринки товарів та послуг, що забезпечить здійснення будь-якого виду зовнішньоекономічної діяльності на основі законодавства країн-учасників торгівлі та за допомогою основних методів стратегічного управління, спрямованих на розвиток внутрішнього та зовнішнього середовища підприємства з метою встановлення партнерських та торгівельних зв'язків і нарощення конкурентних переваг.

На основі розглянутих визначень відомих науковців та враховуючи характеристику сфери сільського господарства України, варто виділити такі ознаки стратегії зовнішньоекономічної діяльності саме у цій сфрері:

- спрямованість на внутрішнє та зовнішнє середовище функціонування підприємства;

- комплексність та взаємозв'язок з іншими видами стратегій підприємства;

- важливість врахування всіх факторів, ризиків та ймовірних ситуацій;

-включення пріоритетних напрямків зовнішньоекономічної діяльності в розробку та впровадження стратегії;

- інтенсивний розвиток галузі сільського господарства України;

- наявність природніх ресурсів для активного розвитку стратегічного потенціалу галузі;

- сприятливий мікро- та макроклімат для міжнародної торгівлі та всіх інших видів зовнішньоекономічної діяльності у сфері сільськогосподарського господарства України; операції;

- відповідність стандартам якості та сертифікації країн, які здійснюють торгово-виробничі

- спрямованість на досягнення поставлених цілей всіма суб'єктами зовнішньоекономічної діяльності (суб'єктами мікрорівня, суб'єктами макрорівня та суб'єктами міждержавного рівня);

- регулюється принципами діяльності, які зазначені в ст. 2 Законі України «Про зовнішньоекономічну діяльність» № 959-XII від 16 квітня 1991 р. [6].

Стратегічне управління на підприємствах сільського господарства України виражається у певних функціях, які зображені на рис. 1. Здійснення даних функцій на сільськогосподарському підприємстві відбувається за допомогою стратегічних рішень, які характеризуються інноваційним характером, спрямованістю на основні цілі та потенційні можливості сільськогосподарського підприємства, суб'єктивність оцінки діяльності підприємства та його виробничого потенціалу і високим рівнем ризику діяльності на ринках товарів та послуг.

Для ефрективного фрункціонування стратегічного управління на сільськогосподарському підприємстві можна виділити таких п'ять основних функцій, як: планування стратегії, організація виконання стратегічного плану, координація з реалізації стратегічних завдань, мотивація за досягнуті стратегічні результати та контроль за процесом виконання стратегії.

1. Планування стратегії - це процес прийняття управлінських рішень, які мають на меті формування самої стратегії, розподілу всіх наявних ресурсів підприємства, адаптації компанії до зовнішнього середовища, внутрішньої організації. Цей процес посідає ключове місце в системі стратегічного управління підприємством. Для багатьох західних та східних компаній стратегічне планування $€$ головним інструментом, щоб змінити внутрішнє середовище компанії, та вийти 3 кризових ситуацій, які сформувались у зовнішньому та внутрішньому середовищі функціонування. Він включає в себе виконання таких функцій, як прогнозування, розробка стратегії та бюджетування. Функція прогнозування базується на ґрунтовному проведенні аналізу внутрішніх та зовнішніх умов та їх факторах функціонування підприємства, головною метою якої $€$ передбачити та спрогнозувати можливі ризики, провести їх оцінку, та розробити заходи їх уникнення або мінімізації. Враховуючи результати цього аналізу, менеджмент підприємства формулює місію, бачення, та цілі підприємства, визначає основні перспективні напрямки його розвитку, та розробляє стратегію.

2. Організація виконання стратегічного плану формує майбутній потенціал підприємства, відповідає за узгодження структури та системи управління з обраною стратегією розвитку, забезпечує створення корпоративної культури, яка в свою чергу підтримує стратегію підприємства. 
3. Координація 3 реалізації стратегічних завдань менеджменту сільськогосподарського підприємства полягає у формуванні генеральної стратегії підприємства, її узгодження та реалізація на різних рівнях управління підприємством, відповідно до поставлених цілей, та внутрішніх і зовнішніх умов функціонування сільськогосподарського підприємства.

4. Не менш важливою $€$ функція мотивації за досягнуті стратегічні результати на сільськогосподарському підприємстві. Вона полягає у розробці цілої системи стимулів та важелів впливу на весь персонал підприємства. Кожен працівник, не залежно від посади на підприємстві, залучений до процесу формування та виконання стратегії підприємства. Відповідно, ефективна система стимулів за досягнуті результати буде важливим фрактором мотивації персоналу сільськогосподарського підприємства. Дані стимули можуть бути пов'язані як з матеріальними, так і нематеріальними благами, а також це може бути комплекс цих заходів.

5. Відмінність між поточним та стратегічним контролем - це те, що стратегічний опирається на конкретні показники та ймовірні оцінки діяльності, які потрібно встановлювати на підприємстві. Важливо врахувати, що стратегічний контроль виступає головною формою попереджувального контролю, який виражається у встановленні певної політики, процедур, правил тощо. Саме стратегічний контроль визначає чи можливе подальше стратегічне планування та реалізація обраної стратегії, і чи обрана стратегія забезпечить реалізацію поставлених цілей.

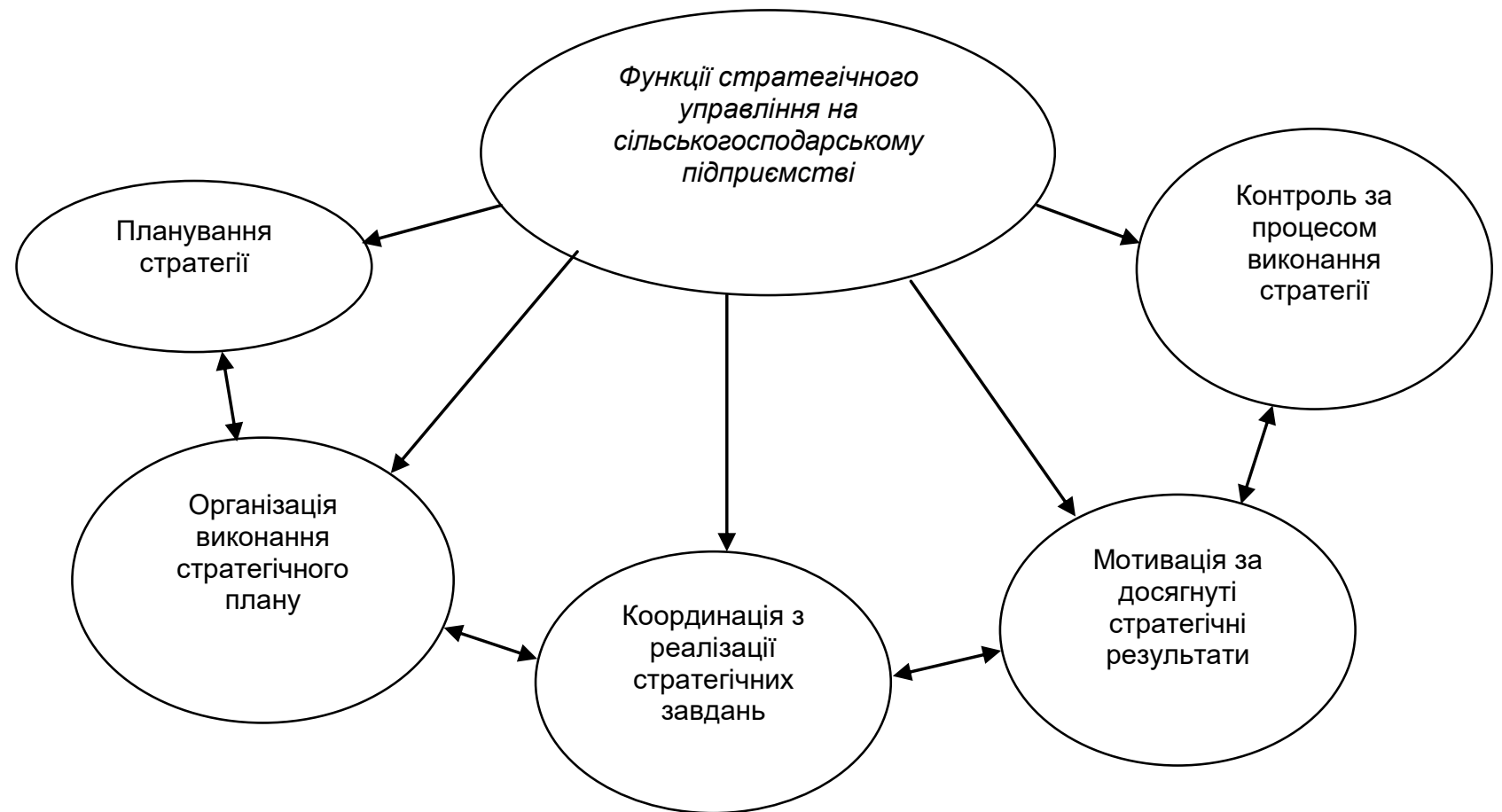

Рис. 1. Функції стратегічного управління розвитком зовнішньоекономічної діяльності на сільськогосподарському підприємстві

Джерело: розробка автора на основі [13-14]

Отже, контроль як управлінська діяльність повинен мати такі властивості: бути всеосяжним та об'єктивним, тобто зорієнтованим на адекватне відображення досягнутих параметрів відносно встановлених цілей та обраних стратегій; бути стратегічно спрямованим, орієнтуватися на кінцеві результати, в цьому контексті контроль розглядається як засіб досягнення цілей; мати безперервний та регулярний, невідворотний плановий характер; бути гнучким, тобто не заважати виконанню основної роботи; відповідати змісту тих робіт, які контролюються, перевіряти не лише кількість і термін, але і якість роботи; бути зрозумілим для тих, кого контролюють і перевіряють; бути своєчасним, щоб можна було скоригувати процеси, що відбуваються; бути економічним, тобто відповідати вимозі: затрати на його проведення не можуть перевищувати ті результати, яких досягають у процесі контролю; бути дієвим, тобто не обмежуватися виявленням фактичного стану об'єкта контролю, а й супроводжуватись відповідними рішеннями [13].

Оскільки немає двох повністю ідентичних підприємств, то немає і двох однакових систем стратегічного управління. Кожне підприємство повинно мати свою власну систему [14]. При розробці та впровадженні системи стратегічного управління саме на сільськогосподарському підприємстві, важливо враховувати саме приналежність до АПК та галузі сільського господарства, та ії особливості, рівень розвитку виробничого потенціалу сільськогосподарського підприємства, розвиток НТП галузі та самого підприємства, інноваційні процеси в галузі та на підприємстві, спеціалізацію підприємства, його тип виробництва та рівень розвитку персоналу, рівень стратегічного мислення менеджменту 
підприємства. Не менш важливим є врахування зовнішнього середовища, а саме політичні, економічні, науково-технічні то соціальні фактори, які зумовлюють динамічний розвиток середовища, в якому функціонує підприємство.

Висновки з проведеного дослідження. Отже, стратегія - це специфічний набір управлінських правил та рішень, який показує основні напрямки розвитку та діяльності підприємства, та є основною ланкою встановлення взаємозв'язків між підприємством та зовнішнім середовищем його функціонування. Вона формується на основі зібраної зовнішньої та внутрішньої інформації та постійно корегується при уточненні цієї інформації. Тобто це генеральний план дій підприємства на його довгострокову перспективу. Не менш важливим є стратегічний аналіз підприємства, який забезпечить правильне формування стратегії та її реалізацію.

Основними функціями стратегії розвитку зовнішньоекономічної діяльності

сільськогосподарського підприємства є:

1. Планування стратегії.

2. Організація виконання стратегічного плану.

3. Координація з реалізації стратегічних завдань менеджменту сільськогосподарського підприємства.

4. Мотивація за досягнуті стратегічні результати.

5. Стратегічний контроль.

Комплексний стратегічний аналіз, чітка стратегія зовнішньоекономічного розвитку відіграють ключову роль у розвитку сільськогосподарських підприємств. Такий підхід забезпечить збільшення обсягів збуту за рахунок ефективного функціонування на зовнішніх ринках, що в свою чергу виводить підприємство з фінансової кризи та забезпечить конкурентоспроможність товару на світовому ринку. Стратегія зовнішньоекономічної діяльності сільськогосподарських підприємств забезпечить попит на їх продукцію, рівень прибутковості цих підприємств та їх життєдіяльність на внутрішніх та зовнішніх ринках. Стратегія повинна обґрунтовувати всі складові діяльності, та врахувати можливі фактори і ризики, бути адаптованою до можливих змін зовнішнього середовища. Адже неправильно вибрана та розроблена стратегія може призвести підприємство до банкрутства.

\section{Література}

1. Кудінов І. О. Понятійний аналіз політичної стратегії. Нова парадигма. 2012. Випуск 110. С. 5565. URL: http://nbuv.gov.ua/j-pdf/Nopa_2012_110_9.pdf (дата звернення: 20.12.2020).

2. Henry Mintzberg. The Strategy Concept I: Five Ps For Strategy. California Management Review. 2001. Pp. 11-24.

3. Ансоффф И. Стратегическое управление / сокр. пер. с англ. ; науч. ред. и авт. предисл. Л. И. Евенко. Москва : Экономика, 1989. 519 с.

4. Портер Майкл Е. Стратегія конкуренції / пер. з англ. А. Олійник, Р. Сільський. Київ : Основи, 1997. 390 c.

5. Дойль П. Менеджмент: стратегия и тактика. СПб. : Питер, 1999. 560 с.

6. Карлоф Б. Деловая стратегия / пер. с анг. О. Д. Горин. Москва : Экономика, 1991. 240 с.

7. Про зовнішньоекономічну діяльність : Закон України в редакції від 25.04.2008 p. № 959-XII. URL: http://zakon.rada.gov.ua/cgi-bin/laws/main.cgi?nreg=959-12 (дата звернення: 20.12.2020).

8. Кісь О. П. Формування стратегії зовнішньоекономічної діяльності підприємства : автореф. дис. на здобуття наук. ступеня канд. ХНЕУ. Харків, 2005. 21 с.

9. Кириченко О. А. Менеджмент зовнішньоекономічної діяльності : навч. посібник. 3-тє вид., переробл. і доп. Київ : Знання-Прес, 2002. 384 с.

10.Косенко С. В. Теоретичні положення зовнішньоекономічної діяльності підприємства: визначення та класифікація. Економіка та управління підприємствами машинобудівної галузі. 2011. № 3. С. 117-128.

11.Дергачов В. А. Международные экономические отношения : учебник для вузов. Москва : ЮНИТИ-ДАНА, 2005. 368 с.

12.Барабашина Г. В., Качан С. М. Зовнішньоекономічна політика Української держави. URL: http://ea.donntu.org:8080/jspui/bitstream.pdf (дата звернення: 22.12.2020).

13.Данилюк І., Михайлишин Н. Роль стратегічного контролю у системі управління підприємством. Економічний аналіз. 2013. Випуск 12. Частина 3. С. 105-108. URL: http://irbisnbuv.gov.ua/cgi-bin/irbis_nbuv/cgiirbis_64.exe (дата звернення: 20.12.2020).

14.Могильна Л. М. Вдосконалення стратегічного управління сільськогосподарським підприємством. Економіка та суспільство. 2018. Випуск 5. C. 418-424. URL: http://www.economyandsociety.in.ua/journal/15_ukr/64.pdf (дата звернення: 20.12.2020). 


\section{References}

1. Kudinov, O.I. (2012), "Conceptual analysis of political strategy", Nova paradyhma, Issue 110, pp. 55-65, available at: http://nbuv.gov.ua/j-pdf/Nopa_2012_110_9.pdf (access date December 20, 2020).

2. Mintzberg, Henry (2001), "The Strategy Concept I: Five Ps For Strategy", California Management Review, pp. 11-24.

3. Ansoff, I. (1989), Strategicheskoe upravleniye [Strategic Management], Translated from English, ed. by L.I. Evenko, Ekonomika, Moscow, Russia, 519 p.

4. Porter, M.E. (1997), Stratehiia konkurentsii [Competitive Strategy], Translated by A. Oliinyk, R. Silskyi, Osnovy, Kyiv, Ukraine, 390 p.

5. Doyl, P. (1999), Menedzhment: strategiya i taktika [Management: strategy and tactics], Piter, SaintPetersburg, Russia, 560 p.

6. Karlof, B. (1991), Delovaya strategiya [Business strategy], Translated by O. D. Gorin, Ekonomika, Moscow, Russia, 240 p.

7. The Verkhovna Rada of Ukraine (1991), The Law of Ukraine "On Foreign Economic activity" dated 25.04.2008 no. 959-XII, available at: http://zakon.rada.gov.ua/cgi-bin/laws/main.cgi?nreg=959-12 (access date December 20, 2020).

8. Kis, O.P. (2005), "Formation of a strategy of foreign economic activity of the enterprise", Thesis abstract of Cand. Sc. (Econ.), 08.06.01, Kharkiv National Economic University, Kharkiv, Ukraine, 21 p.

9. Kyrychenko, O.A. (2002), Menedzhment zovnishnoekonomichnoi diialnosti [Management of foreign economic activity], tutorial, third edition, Znannia-Pres, Kyiv, Ukraine, 384 p.

10.Kosenko, S.V. (2011), "Theoretic provisions of foreign economic activity of the enterprise: definitions and classification", Ekonomika ta upravlinnia pidpryiemstvamy mashynobudivnoi haluzi, no. 3, pp. 117-128.

11.Dergachev, V.A. (2005), Mezhdunarodnyye ekonomicheskiye otnosheniya [Foreign economic relations], high-school textbook, YuNITI-DANA, Moscow, Russia, 368 p.

12.Barabashyna, H.V. and Kachan, S.M. (2012), "Foreign economic activity of Ukraine", available at: http://ea.donntu.org:8080/jspui/bitstream.pdf (access date December 22, 2020).

13.Danyliuk, I. and Mykhailyshyn, N. (2013), "Role of the strategic control in the system of enterprise administration", Ekonomichnyi analiz, Issue 12, Part 3, pp. 105-108, available at: http://irbis-nbuv.gov.ua/cgibin/irbis_nbuv/cgiirbis_64.exe (access date December 20, 2020).

14. Mohylna, L.M. (2018), "Improvement of strategic administration of an agricultural enterprise", Ekonomika ta suspilstvo, Issue 5, pp. 418-424, available at: http://www.economyandsociety.in.ua/journal/15_ukr/64.pdf (access date December 20, 2020). 